\title{
Karakteristik Asap Cair Hasil Pirolisis dari Bagian Batang Bambu Tabah (Gigantochloa nigrociliata BUSE-KURZ) yang Berbeda
}

\section{Characteristics of Liquid Smoke of Pyrolysis Results From Different Tabah Bamboo Stem (Gigantochloa nigrociliata BUSE-KURZ)}

\author{
Cokorda Mira Devi, Pande Ketut Diah Kencana, Gede Arda \\ Program Studi Teknik Pertanian, Fakultas Teknologi Pertanian, Universitas Udayana \\ *email: diahkencana@unud.ac.id
}

\begin{abstract}
Abstrak
Tujuan penelitian ini adalah mengetahui berapa rendemen asap cair batang bambu tabah bagian atas, tengah, dan bawah yang dihasilkan dari proses pirolisis pada saat suhu mencapai $200^{\circ} \mathrm{C}$ serta kandungan senyawa kimianya ( $\mathrm{pH}$, total asam, total fenol). Penelitian ini menggunakan Rancangan Acak Lengkap (RAL) dengan faktor tunggal yaitu bagian dari batang bambu yang berbeda. Hasil penelitian menunjukkan bahwa perbedan bagian batang bambu berpengaruh terhadap karakteristik asap cair yang diperoleh. Batang bambu bagian bawah menghasilkan rendemen $(46,44 \%)$, total fenol $(2,79)$, dan persentase arang $(58,40 \%)$ paling tinggi. Sedangkan total asam $(12,36 \%)$ dan $\mathrm{pH}(4,10)$ tertinggi masing-masing diperoleh dari batang tengah dan batang atas. Analisis beda nyata terkecil menunjukkan perbedaan batang atas, tengah dan bawah berpengaruh nyata terhadap hasil rendemen, total fenol, dan persentase arang.
\end{abstract}

Kata kunci: asap cair, batang bambu tabah, pirolisis

\begin{abstract}
The purpose of this study is to find out how the yield of the upper, middle and lower stems of liquid bamboo stems produced from the pyrolysis process when the temperature reached $200^{\circ} \mathrm{C}$ and the chemical content $(\mathrm{pH}$, total acid, total phenol). This study uses a Completely Randomized Design (CRD) with a single factor, which is part of a different bamboo stem. The results of the study showed that the differences in the bamboo culms affected the characteristics of the liquid smoke obtained. The lower bamboo stem produce the highest rendemen (46,44\%), the highest total phenol (2.79), and the highest percentage of charcoal (58.40\%). While the highest total acid (12.36\%) and the highest $\mathrm{pH}(4.10)$ were obtained from the middle stem and upper stem, respectively. The smallest real difference analysis showed differences in the upper, middle and lower stems significantly affected the rendemen, total phenol, and charcoal percentage.
\end{abstract}

Keyword: pyrolysis temperature, smoke liquid, tabah bamboo stem

\section{PENDAHULUAN}

Bambu merupakan hasil hutan non kayu yang memiliki potensi potensi besar untuk dikembangkan menjadi bahan baku industri. Terdapat \pm 40 jenis bambu yang dapat tumbuh baik di Bali dari 161 jenis bambu yang tumbuh di Indonesia. Kencana et al., (2012) menyatakan bahwa salah satu jenis bambu yang dapat tumbuh baik di Bali khususnya di daerah Pupuan, Kabupaten Tabanan adalah bambu tabah (Gigantochloa nigrociliata BUSE-KURZ). Pada awalnya, tanaman bambu tabah merupakan tanaman liar yang banyak tumbuh di tepian sungai, hutan, lereng gunung yang memiliki fungsi sebagai penyangga tanah agar tidak mengalami longsor.

Menurut Berlian dan Rahayu dalam Loiwatu \& Manuhuwa (2008) bagian batang bambu dapat dimanfaatkan sebagai bahan bangunan seperti dinding rumah, rangka kuda-kuda, tiang, pintu, kusen jendala dan atap. Selain itu, batang bambu juga bisa dimanfaatkan menjadi berbagai macam peralatan rumah tangga seperti kap lampu, keranjang, tempat nasi, kerai, tikar, taplak alas makan, dan lainnya. Batang bambu juga dimanfaatkan untuk dijadikan barang kerajinan serta anyaman, meja, kursi dan juga tempat tidur. Hal yang menyebabkan batang bambu bisa lebih mudah dibentuk dibandingkan kayu adalah karena bambu mengandung lignin, lignin yang terkandung dalam batang bambu memungkinkan bambu menjadi lebih mudah dibentuk dengan cara memanaskannya karena lignin mempunyai sifat termoplastik. Sifat termoplastik dari lignin memungkinkan bambu dapat dibentuk dalam kondisi panas tetapi setelah bambu mendingin bentuk bambu tidak berubah kembali ke bentuk yang semula (perubahan bentuk tetap).

Menurut Darmadji (1996) asap cair merupakan suatu hasil kondensasi atau pengembunan dari uap hasil 
pembakaran dari bahan-bahan yang mengandung lignin, selulosa, hemiselulosa serta senyawa karbon lainnya. Pembakaran dapat berupa pembakaran secara langsung maupun pembakaran secara tidak langsung. Asap cair bisa juga diartikan sebagai hasil pendinginan dan pencairan asap yang bahannya dibakar dalam tabung dengan kondisi tertutup. Asap yang awal mulanya berwujud partikel padat didinginkan yang kemudian menjadi cair itu disebut asap cair.

Asap mempunyai kandungan senyawa asam, fenol, dan karbonil yang dapat menyebabkan asap bisa mengawetkan bahan makanan atau berfungsi sebagai pengawet makanan alami. Seperti yang dilaporkan Darmaji et al., (2007) bahwa hasil dari pirolisis pembakaran tempurung kelapa dapat menghasilkan asap cair yang mengandung senyawa fenol sebanyak $4,13 \%$, karbonil sebanyak $11 \%$ dan senyawa asam sebanyak 10,2\%. Negara Amerika Serikat telah mengaplikasikan penggunaan asap cair untuk pengawetan bahan pangan seperti daging dan ikan, dimana asap cair yang digunakan untuk mengawetkan telah melalui proses penyaringan serta pemisahan senyawa tar.

Menurut Sumasroh (2010) komposisi dari asap cair bergantung pada bahan bakunya yang meliputi kadar air, ukuran partikel bahan, jenis, suhu pembakaran serta kecukupan oksigen dan tahapan proses. Dari mengetahui karakteristik asap cair batang bambu tabah yang di pirolisis dengan suhu berbeda dan bagian batang yang berbeda serta memaksimalkan dalam pemanfaatannya bambu tabah, dalam pembuatan asap cair maka perlu adanya suatu kajian untuk mengetahui kandungan apa saja yang terdapat pada asap cair batang bambu tabah yang berguna sebagai pengawet dan hal ini akan memberikan manfaat kepada masyarakat pada umumnya dan meningkatkan nilai pada bambu khususnya bambu tabah.

Menurut Loiwatu \& Manuhuwa (2008) komponen kimia batang bambu bagian bawah berbeda secara signifikan dibandingkan dengan batang bambu bagian tengah dan atas. Batang bambu bagian bawah mengandung alfa selulosa $(46,04 \%)$ dan lignin $(26,67 \%)$ relatif lebih banyak daripada batang bambu bagian tengah $(44,98 \% ; 26,57 \%)$ dan batang bambu bagian atas $(43,89 \% ; 26,36 \%)$. Hasil penelitian Ulfah dalam Loiwatu \& Manuhuwa (2008) pada tiga jenis bambu menunjukkan kecenderungan yang sama pada kadar alfa selulosa batang bambu bagian bawah $(45,38 \%)$ lebih banyak daripada batang bambu bagian tengah $(44,48 \%)$ dan pada batang bambu bagian atas (43,68\%). Kandungan lignin yang dianalisis pada penelitian tersebut menunjukkan bahwa pada batang bambu bagian bawah $(25,64 \%)$ lebih rendah dibandingkan dengan batang bambu bagian tengah $(25,99 \%)$ dan pada batang bambu bagian atas menunjukkan nilai paling tinggi yaitu $(26,22 \%)$.

Dari hasil penelitian diatas, belum ada kajian karakteristik asap cair hasil pirolisis yang diproduksi dari bambu tabah dengan bagian batang yang berbeda (batang bagian atas, batang bagian tengah, dan batang bagian bawah).

\section{Tujuan}

Tujuan dilakukannya penelitian ini adalah untuk megetahui berapa rendemen asap cair batang bambu tabah bagian atas, tengah, dan bawah yang dihasilkan dari proses pirolisis pada saat suhu mencapai $200^{\circ} \mathrm{C}$. Dari penelitian ini diharapkan dapat mengetahui kandungan senyawa kimia $(\mathrm{pH}$, total asam, total fenol) yang dihasilkan dari pirolisis batang bambu tabah bagian atas, tengah, dan bawah.

\section{METODE PENELITIAN}

\section{Waktu dan Tempat}

Penelitian ini dilakukan di Laboratorium Ergonomika dan Perancangan Fakultas Teknologi Pertanian Universitas Udayana, mengukur densitas pada Laboratorium Analisis Pangan Fakultas Teknologi Pertanian Universitas Udayana, Greenhouse Fakultas Teknologi Pertanian Universitas Udayana untuk menjemur bahan, dan Laboratorium Analitik Universitas Udayana untuk menganalisis rendemen hasil pirolisis. Penelitian dilaksanakan mulai bulan Juni 2018 sampai Agustus 2018.

\section{Bahan dan Alat Penelitian}

Bahan yang digunakan pada penelitian ini adalah batang bambu tabah yang telah dipotong secara proporsional dan dibagi menjadi 3 bagian yaitu bagian atas, tengah, dan bawah. Bambu selanjutnya dipotong menjadi bagian yang lebih kecil dengan panjang $5 \mathrm{~cm}$. Diameter bambu berkisar antara 4-6 $\mathrm{cm}$. Bambu di dapat dari kebun bambu tabah di Desa Padangan, Kecamatan Pupuan, Kabupaten Tabanan. Alat yang digunakan dalam penelitian ini merupakan satu unit alat pirolisator asap cair yang terdiri dari reaktor pirolisis dan kondensor yang memiliki kapasitas $3 \mathrm{~kg}$, alat pemotong berupa gergaji manual untuk memotong pohon bambu dan pemotong listrik untuk memotong bambu menjadi ukuran lebih kecil $(5 \mathrm{~cm})$, gelas ukur kapasitas 1 liter untuk mengukur rendemen, karung kapasitas $50 \mathrm{~kg}$ untuk menampung bambu, timbangan duduk merk Q2 8320 kapasitas 20 $\mathrm{kg}$, botol plastik kapasitas 1 liter, corong plastik, dan kertas saring whatman ukuran 42 .

\section{Rancangan Penelitian}

Penelitian ini menggunakan Rancangan Acak Lengkap (RAL) dengan faktor tunggal yaitu bahan 
baku diambil dari bagian bambu yang berbeda (bagian atas, tengah, dan bawah). Setiap percobaan diulang sebanyak 5 kali ulangan, sehingga didapatkan 15 satuan percobaan. Data hasil penelitian dianalisis dengan analisis varians (Analysis of Variance. ANOVA). Jika pada analisis menggunakan ANOVA terjadi pengaruh terhadap variabel yang diamati, maka selanjutnya akan dilakukan uji BNT (Beda Nyata Terkecil). Tujuan dilakukannya uji BNT adalah untuk mengetahui adanya perbedaan atau tidak dari pemberian perlakuan yang dilakukan serta mengetahui perlakuan mana yang mendapat hasil perlakuan terbaik.

\section{Prosedur Penelitian \\ Persiapan Bahan}

Bambu tabah (Gigantochloa nigrocilliata BUSEKURZ) diperoleh dari Desa Padangan, Kecamatan Pupuan, Kabupaten Tabanan. Bambu yang telah berumur 2 tahun dipotong manual menggunakan gergaji. Sebelum dipotong menjadi bagian yang berbeda, batang bambu dipotong 1 meter dari pangkal dan ujung untuk menyeragamkan ukuran bambu. Batang bambu yang berbeda diperoleh dengan cara membagi batang bambu menjadi 3 bagian secara proposional sebagai bambu bagian atas, tengah, dan bawah. Setelah itu batang bambu bagian atas, tengah, dan bawah dipotong menjadi ukuran yang lebih kecil dengan panjang $5 \mathrm{~cm}$. Masing-masing bagian bambu dimasukkan ke dalam karung dan diberikan label. Selanjutnya bambu dibawa ke greenhouse Fakultas Teknologi Pertanian Universitas Udayana dan dijemur selama 7 hari yang bertujuan untuk menyeragamkan kandungan kadar air pada bahan.

\section{Proses Pembuatan Asap Cair}

Proses pembuatan asap cair mengacu pada Darmaji et al., (1999). Setiap percobaan menggunakan bambu yang sudah di potong menjadi $5 \mathrm{~cm}$ sebanyak $3 \mathrm{~kg}$. Total bambu tabah yang digunakan dalam penelitian ini adalah sebanyak $45 \mathrm{~kg}$. Bambu kemudian dimasukan kedalam reaktor pirolisis. Selanjutnya setelah bambu dimasukan, tutup tabung pirolisis dengan rapat. Setelah tabung ditutup, nyalakan alat pirolisis dan tunggu hingga suhu mencapai $200^{\circ} \mathrm{C}$.

\section{Parameter yang Diamati}

Parameter yang diamati yaitu rendemen, densitas, $\mathrm{pH}$, total asam, total fenol, dan persentase arang.

\section{HASIL DAN PEMBAHASAN}

\section{Rendemen}

Rendemen merupakan parameter paling penting yang digunakan untuk mengetahui hasil dari proses pirolisis. Berdasarkan hasil uji beda nyata terkecil dan uji sidik ragam menunjukkan bahwa perbedaan batang bambu bagian atas, tengah, dan bawah berpengaruh signifikan terhadap jumlah rendemen yang dihasilkan.

Dari hasil pirolisis batang bambu tabah bagian atas, tengah, dan bawah menghasilkan rendemen asap cair berkisar antara 35,58\%-46,44\%. Rendemen asap cair hasil pirolisis bambu tabah lebih tinggi dari hasil pirolisis bambu hitam, bambu tutul, dan bambu betung pada penelitian Komarayati \& Wibowo (2015) yang berkisar Antara 5,00\%-24,00\%.

Perbedaan dari jumlah rendemen asap cair yang dihasilkan dapat disebabkan karena perbedaan jenis bahan baku yang digunakan, yang paling utama adalah karena perbedaan kandungan kadar lignin dan selulosa (Trenggono et al., 1997 dalam Wibowo, 2012). Menurut Loiwatu \& Manuhuwa (2008) komponen kimia dari bagian bawah batang berbeda signifikan terhadap bagian tengah dan bagian atas batang bambu. Ulfah (1999) menemukan bahwa pada tiga jenis bambu yang berbeda terhadap bagian batang bambu yang berbeda, didapat hasil berupa alfa selulosa dari batang bambu bagian bawah sebesar 45,38\% lebih banyak dibandingkan nilai alfa selulosa batang bambu bagian tengah $44,48 \%$, dan batang bambu bagian atas memiliki nilai alfa selulosa paling kecil yaitu $43,68 \%$.

Batang bambu tabah bagian bawah memiliki jumlah persentase rata-rata rendemen asap cair yang lebih besar dibandingkan jumlah persentase rata-rata rendemen asap cair batang bambu bagian tengah dan atas. Batang bambu tabah bagian bawah memiliki persentase rata-rata rendemen asap cair sebesar $46,44 \%$ dimana persentase rata-rata rendemen tersebut 6,49\% lebih banyak dari persentase rata-rata rendemen asap cair yang dihasilkan oleh batang bambu tabah bagian tengah yaitu 39,95\%. Batang bambu tabah bagian atas memiliki persentase ratarata rendemen asap cair yang paling kecil yaitu $35,75 \%$.

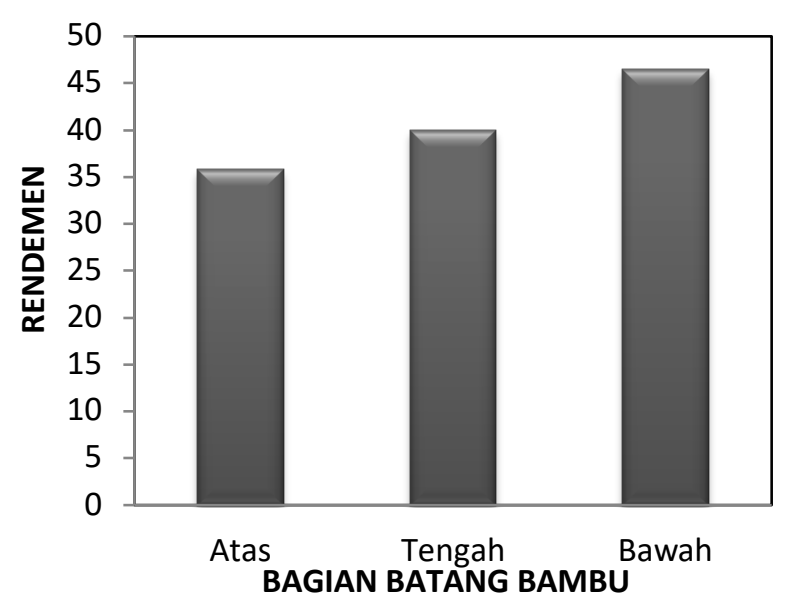


Gambar 1. Grafik rata-rata persentase rendemen asap cair hasil pirolisis batang bambu tabah dari bagian batang bambu yang berbeda

\section{Densitas}

Surest et al., (2013) menyatakan bahwa desitas (berat jenis) merupakan pengukuran dari masa jenis suatu zat degan masa jenis murni dari air. Densitas merupakan pengukuran massa dari tiap satuan volume benda, massa jenis berfungsi untuk menentukan zat. Massa jenis rata-rata dari setiap benda merupkan total dari massa dibagi total volumenya.

Densitas asap cair hasil pirolisis dari bagian batang bambu tabah yang berbeda menunjukkan nilai berkisar antara 1,0386-1,0397 g/ml. Nilai densitas asap cair yang diperoleh lebih besar dari penelitian yang dilakukan Alpian et al., (2014) yang berkisar atara $1,008-1,052 \mathrm{~g} / \mathrm{ml}$ dan penelitian yang dilakukan oleh Nurhayati (2006) yang berkisar antara 1,004$1,018 \mathrm{~g} / \mathrm{ml}$. Hasil penelitian ini sudah memenuhi standar mutu dari asap cair spesifikasi Jepang dengan berat jenis $>1,005$.

Densitas asap cair pirolisis batang bambu tabah bagian atas memiliki nilai $1,03934 \mathrm{~g} / \mathrm{ml}$, batang bambu tabah batang tengah memiliki nilai densitas paling kecil 1,0386 g/ml, dan batang bambu tabah bagian bawah memiliki nilai paling tinggi yaitu 1,0397

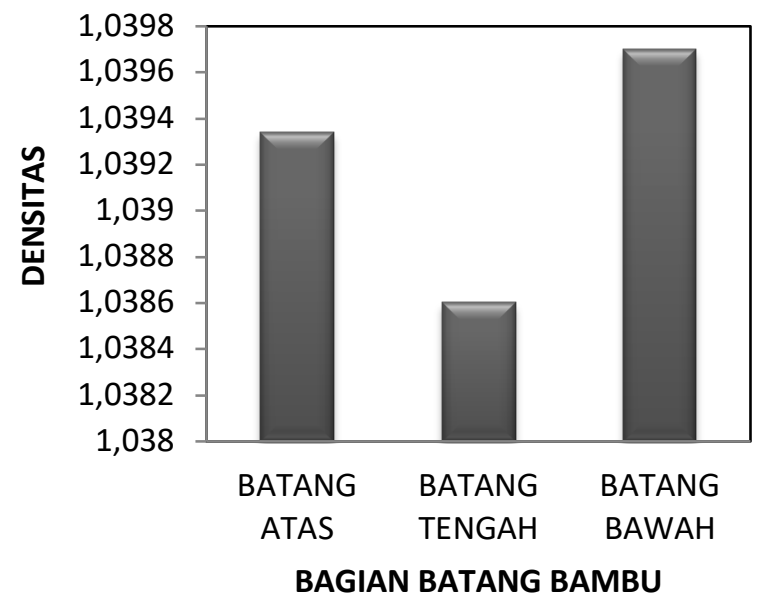

Gambar 2. Grafik rata-rata persentase densitas asap cair hasil pirolisis batang bambu tabah dari bagian batang bambu yang berbeda

\section{pH}

Dilakukannya pengukuran $\mathrm{pH}$ bertujuan untuk mengetahui derajat yang menunjukkan tingkat kadar keasaman atau kebasaan suatu larutan. $\mathrm{pH}$ merupakan faktor penting yang dapat berpengaruh terhadap laju pertumbuhan mikroorganisme, $\mathrm{pH}$ rendah dapat menghambat laju pertumbuhan dari mikroorganisme. $\mathrm{pH}$ berkaitan erat dengan total asam, semakin rendah suatu $\mathrm{pH}$ maka semakin asam suatu cairan. Asap cair hail pirolisis batang bambu tabah bagian atas, tengah, dan bawah menunjukkan nilai $\mathrm{pH}$ berkisar Antara 3,79-4,12 lebih tinggi dibandingkan dengan $\mathrm{pH}$ asap cair hasil pirolisis kulit kakao $(2,9)$, sabut kelapa sawit $(3,1)$, kulit kopi $(3,1)$, sabut kelapa 3,16, pH tempurung kelapa $(3,2)$ dan cangkang sawit $(3,29)$ (Darmadji, 1996; Sih Yuwanti, 2003; Halim et al, 2004)

Rata-rata $\mathrm{pH}$ asap cair paling rendah terdapat pada asap cair batang bambu tabah bagian tengah yaitu 3,87 , sehingga $\mathrm{pH}$ asap cair batang bambu tabah bagian tengah merupakan $\mathrm{pH}$ yang paling asam diantara $\mathrm{pH}$ asap cair yang dihasilkan dari bagian batang bambu tabah yang lainnya. Menurut Alpian et al., (2014) nilai $\mathrm{pH}$ yang rendah menunjukkan asap yang dihasilkan berkualitas tinggi dan paling baik penggunaannya sebagai bahan pengawet makanan. Nilai $\mathrm{pH}$ rendah secara keseluruhan berpengaruh terhadap lama daya simpan dari suatu produk yang diawetkan. Nilai rata-rata $\mathrm{pH}$ dari asap cair batang bambu tabah bagian bawah adalah 3,89, dan rata-rata $\mathrm{pH}$ asap cair batang bambu tabah bagian atas menunjukkan nilai $\mathrm{pH}$ paling tinggi yaitu 4,10.

Berdasarkan uji sidik ragam menunjukkan bahwa perbedaan batang bambu tabah bagian atas, tengah, dan bawah berpengaruh signifikan terhadap nilai $\mathrm{pH}$ asap cair. Berdasarkan uji beda nyata terkecil, perlakuan perbedaan batang atas dan batang bawah berpengaruh nyata terhadap nilai $\mathrm{pH}$ sedangkan perbedaan batang bawah dengan batang tengah tidak berbeda nyata.

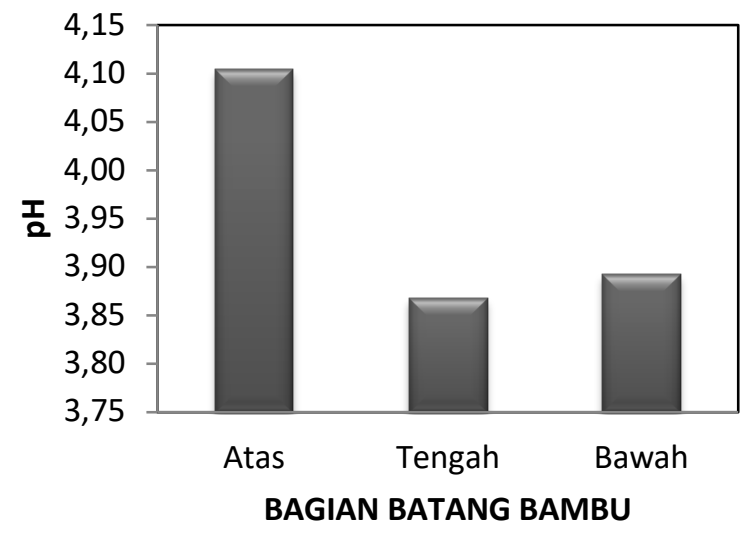

Gambar 3. Grafik rata-rata nilai $\mathrm{pH}$ asap cair hasil pirolisis bagian batang bambu tabah dari bagian batang bambu yang berbeda

\section{Total Asam}

Asam yang berbentuk cairan atau cuka kayu dapat mempengaruhi keseluruhan jumlah asam. Keasaman yang dimiliki cuka kayu berfungsi untuk mengkondisikan $\mathrm{pH}$ alami dari cuka kayu yang mempunyai sifat mengawetkan atau sebagai pengawet, hal ini dikemukakan oleh Girrard (1992). Menurut Rahmalinda et al., (2008) senyawa yang paling banyak terkandung pada asap cair hasil dari 
pirolisis adalah kelompok senyawa asam karboksilat, ini disebabkan oleh adanya kadar selulosa dan hemiselulosa yang terdapat pada bahan. Semakin banyak selulosa dan hemiselulosa yang terdapat pada bahan, maka semakin banyak kelompok senyawa asam karboksilat yang terdapat pada asap cair.

Total asam asap cair hasil pirolisis batang bambu tabah bagian atas, tengan, dam bawah berkisar antara $11,25 \%-12,35 \%$ lebih tinggi dari total asam asap cair tempurung nyamplung pada penelitian Wibowo (2012) yang berkisar antara 4,19\%-9,48\% dan total asap cair tempurung kelapa pada penelitian Marasabessy (2007) yang berkisar antara 9,45\%$10,15 \%$.

Persentase total asam asap cair batang bambu tabah bagian atas memiliki nilai $11,25 \%-11,33 \%$, nilai total asam asap cair batang bambu tabah bagian tengah adalah $12,29 \%-12,51 \%$, dan nilai total asam asap cair batang bambu tabah bagian bawah adalah 12,19\%$12,35 \%$. Nilai rata-rata persentase total asam asap cair hasil pirolisis dari bagian batang bambu yang berbeda menunjukkan rata-rata persentase asam paling tinggi adalah persentase asap cair hasil pirolisis dari batang bambu bagian tengah yaitu $12,36 \%$, sehingga asap cair batang bambu bagian tengah memiliki $\mathrm{pH}$ paling rendah diantara lainnya. Rata-rata persentase total asam asap cair bambu tabah bagian bawah adalah 12,29\%. Sedangkan ratarata persentase total asam yang paling rendah adalah persentase total asam asap cair batang bambu tabah bagian atas $11,28 \%$, sehingga $\mathrm{pH}$ asap cair batang bambu bagian atas merupakan nilai $\mathrm{pH}$ paling tinggi diantara asap cair hasil pirolisis batang bambu tabah dari bagian batang yang berbeda.

Hasil uji sidik ragam menunjukkan bahwa perbedaan batang bambu tabah bagian atas, tengah, dan bawah berpengaruh signifikan terhadap persentase total asam asap cair. Berdasarkan uji beda nyata terkecil, perlakuan perbedaan batang atas dan batang tengah berpengaruh nyata terhadap nilai persentase total asam sedangkan perbedaan batang bawah dengan batang tengah tidak terlalu berbeda nyata.

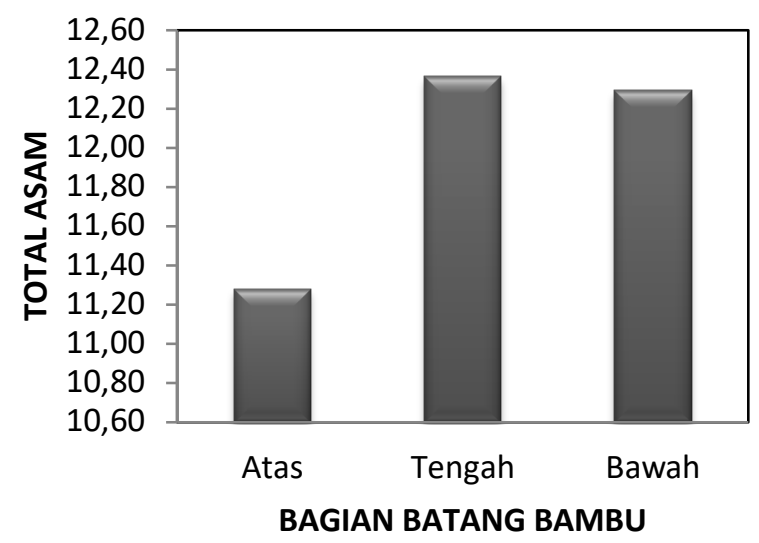

BAGIAN BATANG BAMBU
Gambar 4. Grafik rata-rata persentase total asam asap cair hasil pirolisis bagian batang bambu tabah dari bagian batang bambu yang berbeda

\section{Total Fenol}

Fenol berperan sebagai pengontrol pertumbuhan mikroba dan memiliki aktivitas anti oksidan yang cukup besar sehingga dapat memperpanjang masa simpan suatu produk (Pzszola, 1995). Fenol dihasilkan dari pirolisis selulosa serta pirolisis lignin yang menghasilkan fenol dan derivatnya. Dari hasil penelitian Ulfah (1999) batang bambu bagian bawah memiliki kandungan lignin paling rendah yaitu $(25,64 \%)$, batang bambu bagian tengah memiliki kandungan lignin $(25,99 \%)$, dan batang bambu bagian atas memiliki kandungan lignin paling banyak yaitu $(26,22 \%)$.

Kadar total fenol dipengaruhi oleh suhu. Pada suhu $200^{\circ} \mathrm{C}$ lignin belum terurai sehingga mempengaruhi persentase total fenol yang dihasilkan. Kandungan fenol asap cair tongkol jagung 2,03\%-2,37\% (Aulia, 2011). Kandungan fenol asap cair tempurung nyamplung $0,66 \%-4,19 \%$, kandungan fenol asap cair tempurung kelapa 0,6-2,76\% (Marasabessy, 2007). Total fenol asap cair hasil pirolisis batang bambu tabah bagian atas, tengah, dan bawah berkisar antara $2,49 \%-2,81 \%$.

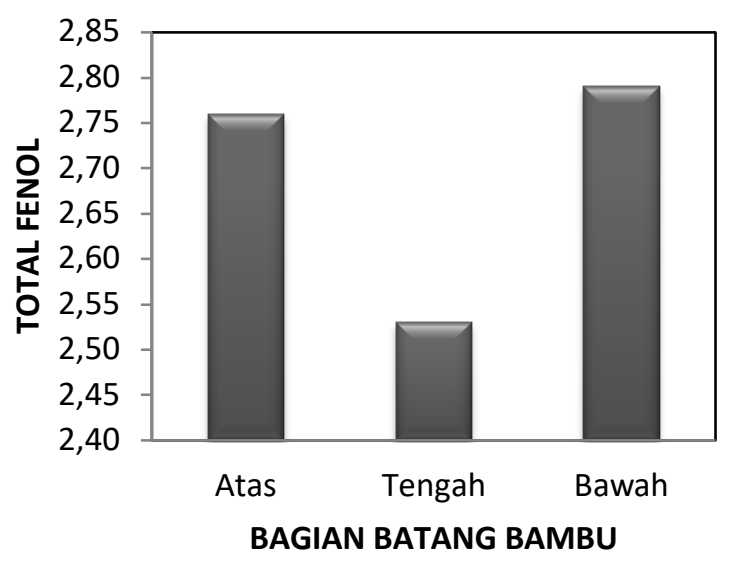

Gambar 5. Grafik rata-rata persentase total fenol asap cair hasil pirolisis bagian batang bambu tabah dari bagian batang bambu yang berbeda

Total fenol yang dihasilkan dari pirolisis batang bambu tabah dengan bagian batang bambu yang berbeda memiliki hasil total fenol yang berbeda. Persentase total fenol asap cair batang bambu tabah bagian atas 2,74\%-2,77\%, persentase total fenol asap cair batang bambu tabah bagian tengah 2,49\%$2,57 \%$, dan bambu tabah bagian bawah memiliki persentase total frnol $2,77 \%-2,81 \%$. Persentase ratarata total fenol paling tinggi dihasilkan oleh pirolisis asap cair batang bambu tabah bagian bawah yaitu sebanyak $2,79 \%$, nilai rata-rata total fenol hasil 
pirolisis batang bambu tabah bagian atas memiliki nilai $2,76 \%$ dimana tidak terlalu berbeda jauh dengan nilai fenol batang bambu tabah bagian bawah. Sesuai pernyataan Yudoyono (1999) turunnya kadar fenol disebabkan oleh kadar air yang tinggi, karena tercampurnya hasil kondensasi uap air. Total fenol hasil pirolisis batang bambu tabah bagian tengah memiliki nilai rata-rata paling kecil yaitu $2,53 \%$, hal ini dikarenakan batang bambu tabah bagian tengah memiliki kadar air yang paling tinggi yaitu 7,70\%. Bisa dilihat pada tabel kadar air bahan dibawah.

Tabel 1.

\begin{tabular}{ll} 
Kadar air bahan & \\
\hline Batang Bambu Tabah & Kadar Air \\
Batang Atas & $6,67 \%$ \\
Batang Tengah & $7,70 \%$ \\
Batang Bawah & $7,18 \%$ \\
\hline
\end{tabular}

Hasil uji sidik ragam dan uji beda nyata terkecil menunjukkan bahwa perbedaan batang bambu tabah bagian atas, tengah, dan bawah berpengaruh signifikan terhadap persentase total fenol asap cair hasil pirolisis batang bambu tabah.

\section{Persentase Arang}

Arang merupakan residu hitam yang mengandung karbon tidak murni, arang umumnya terdiri dari $85 \%$ 98\% karbon. Arang dan karbon terbentuk karena pada saat proses pirolisis, energi panas memicu terjadinya oksidasi sehingga molekul karbon yang kompleks terurai (Akbar, 2013). Arang ini didapatkan dari sisa hasil proses pirolisis batang bambu tabah dari bagian batang bambu yang berbeda. Menurut Wibowo (2012) arang dapat dimanfaatkan sebagai bahan bakar ataupun sebagai bahan dasar pembuatan arang aktif. Komarayanti et al., (2003) menyatakan bahwa hasil samping pembuatan arang menghasilkan asap cair yang berwarna kuning kecoklatan atau coklat kehitaman.

Pada saat proses pembuatan asap cair juga dihasilkan sisa berupa arang. Pada proses pirolisis batang bambu tabah bagian atas mendapat nilai persentase arang sebanyak 49,67\%-52,67\%, pada proses pirolisis batang bambu tabah bagian tengah nilai persentase arang sebanyak $45 \%-48,33 \%$, dan pada proses pirolisis batang bambu tabah bagian bawah persentase arang sebanyak $56.67 \%-60 \%$.

Jumlah rata-rata persentase arang paling sedikit yaitu persentase arang hasil pembakaran batang bambu tabah bagian tengah $(46,93 \%)$, persentase arang hasil pembakaran batang bambu tabah bagian atas $(51,00 \%)$, dan persentase arang paling banyak yaitu persentase arang hasil pembakaran batang bambu tabah bagian baawah $(58,40 \%)$. Dari hasil uji sidik ragam dan uji beda nyata terkecil menunjukkan bahwa perbedaan batang bambu tabah bagian atas, tengah, dan bawah berpengaruh signifikan terhadap hasil persentase arang pembakaran bambu tabah.

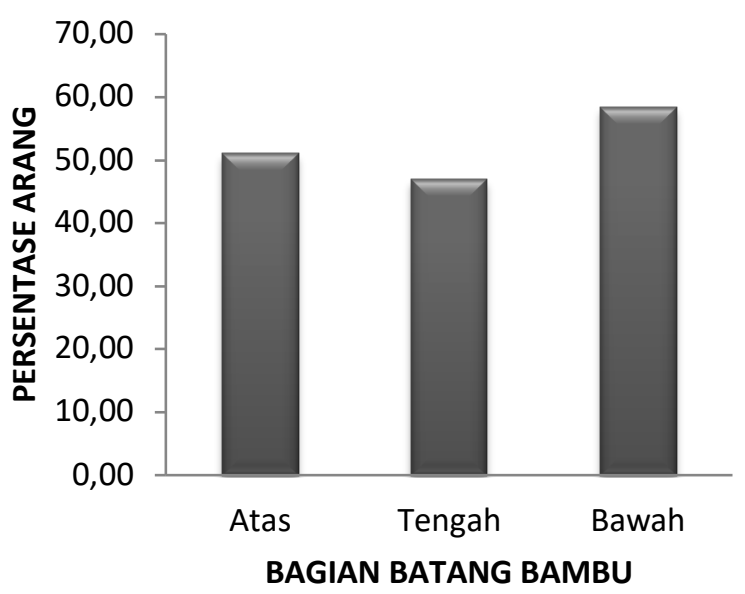

Gambar 6. Grafik rata-rata persentase arang asap cair hasil pirolisis bagian batang bambu tabah dari bagian batang bambu yang berbeda

\section{KESIMPULAN DAN SARAN}

\section{Kesimpulan}

Secara umum, perbedaan batang bambu bagian atas, bagian tengah, dan bagian bawah berpengaruh nyata terhadap hasil rendemen, $\mathrm{pH}$, total asam, total fenol dan persentase arang hasil pirolisis. Asap cair batang bambu bagian atas memiliki nilai $\mathrm{pH}$ paling tinggi yaitu 4,10. Asap cair batang bambu tabah bagian tengah memiliki nilai total asam paling tinggi yaitu $12,36 \%$. Batang bambu bagian bawah memiliki nilai rendemen, desitas, total fenol, dan persentase arang paling tinggi masing-masing $46,44 \%, 1,0397 \mathrm{~g} / \mathrm{ml}$, $2,79 \%$ dan $58,40 \%$

\section{Saran}

Berdasarkan hasil penelitian disarankan untuk proses pirolisis menggunakan suhu yang lebih tinggi dari $200^{\circ} \mathrm{C}$ dan disarankan juga untuk melakukan proses destilasi setelah proses pirolisis

\section{DAFTAR PUSTAKA}

Alpian, Prayitno, T. A., Johanes Pramana Sutapa, G., \& Budiadi. (2014). Kualitas Asap Cair Batang Gelam ( Melaleuca sp .). Juurnal Penelitian Hasil Hutan, 32(2), 83-92..

Darmadji, P. 2006. Perancangan pengolahan sampah kota berwawasan lingkungan berbasis teknologi asap cair.

Komarayati, S., \& Wibowo Pusat Penelitian dan Pengembangan Hasil Hutan Jl Gunung Batu 
No, S. (2014). Karakteristik Asap Cair Dari Tiga Jenis Bambu (Characteristics of Liquid Smoke from Three Bamboo Species), 33(2), 167-174.

Kencana, P. K. D., Widia, W. dan Antara, N. S. 2012. 'Praktek Baik Budi Daya Bambu Rebung Tabah (Gigantochloa nigrociliata BUSEKURZ)', pp. 1-69.

Loiwatu, M., \& Manuhuwa, E. (2008). Komponen kimia dan anatomi tiga jenis bambu dari Seram, Maluku. Agritech, 18(2), 76-83.

Marasabessy I. 2007. Produksi asap cair dari limbah pertanian dan penggunaannya dalam pembuatan ikan tongkol (Euthynnus affinis) asap. Tesis. Program Pascasarjana IPB. Bogor.

Sumasroh M. 2010. Mengenal Asap Cair. Diambil dari

http://www.kebonadem.com/2010/02/mengen al-asap-cair.htmL. Diakses pada tanggal 25 Januari 2018

Surest, A. H., Reza, M. S., \& Priyayi, D. (n.d.). (2013). Bahan Bakar Cair, 19(4), 38-44

Syarif, U. I. N., Jakarta, H., Anisah, K., Kedokteran, F., Ilmu, D. A. N., \& Farmasi, P. S. (2014). Analisa Komponen Kimia dan Uji Antibakteri Asap Cair Tempurung Kelapa Sawit ( Elaeis guineensis Jacq . ) Pada Bakteri Staphylococcus aureus dan Pseudomonas aeruginosa.

Ulfah, D. (1999). Sifat dan Variasi Tiga Jenis Bambu (Apus, Ori, Wulung) pada Ketinggian Tempat Tumbuh yang Berbeda. Thesis UGM. Tidak Dipublikasikan.

Wibowo, S. (2012). Characteristic of Smoke liquid from Nyamplung Shell. Jurnal Penelitian Hasil Hutan, 30(3), 218-227. 